\title{
STRUCTURE AND PROPERTIES OF FeCr, CrAl AND FeCrAl COATINGS DEPOSITED BY CATHODIC ARC EVAPORATION
}

\author{
R.L. Vasilenko ${ }^{1}$, V.N. Voyevodin ${ }^{1,2}$, V.A. Belous ${ }^{1}$, M.A. Bortnitskaya ${ }^{1}$, I.V. Kolodiy ${ }^{1}$, \\ I.O. Klimenko ${ }^{1}$, V.D. Ovcharenko ${ }^{\prime}$, V.I. Kovalenko ${ }^{1}$, V.G. Marinin ${ }^{1}$, A.V. Ilchenko ${ }^{1}$, \\ M.A. Tikhonovsky ${ }^{1}$, A.S. Kuprin ${ }^{1}$ \\ ${ }^{1}$ National Science Center “Kharkov Institute of Physics and Technology”, Kharkiv, Ukraine; \\ ${ }^{2}$ V.N. Karazin Kharkiv National University, Kharkiv, Ukraine \\ E-mail: r.vasilenko@kipt.kharkov.ua
}

Protective coatings with different compositions of $\mathrm{Fe}, \mathrm{Cr}$, and $\mathrm{Al}$ were deposited by cathodic arc evaporation method on fragments of $\mathrm{Zr} 1 \mathrm{Nb}$ alloy fuel claddings. The influence of the composition and structural state of the developed coatings on their physical and mechanical properties (microhardness, resistance to corrosion and cavitation and abrasive wear) has been studied. It is shown that the optimal combination of mechanical properties and high resistance to oxidation from a series of studied coatings $\mathrm{FeCr}$, $\mathrm{FeCrAl}$, and $\mathrm{CrAl}$ have coatings of the $\mathrm{FeCrAl}$ system with a concentration of $\mathrm{Cr} \sim 22$ at.\% and $\mathrm{Al} \sim 14.3$ at.\%. It was found that protective coatings such as $\mathrm{FeCr}, \mathrm{FeCrAl}$, and $\mathrm{CrAl}$ with a thickness of $\sim 12 \mu \mathrm{m}$ significantly increase the resistance to oxidation and prevent the destruction of fuel claddings under oxidation in air at a temperature of $1150{ }^{\circ} \mathrm{C}$ for $1 \mathrm{~h}$.

\section{INTRODUCTION}

Following the severe nuclear accident at Japan's Fukushima nuclear power plant in 2011, the problem of fuel stability with zirconium alloy fuel claddings and the safety of water-cooled reactors have attracted much attention from the scientific community around the world. As a result, the concept of accident-tolerant fuel (ATF) with improved performance during normal operation and in case of accidents was developed [1]. The use of protective coatings to increase the service life and increase safety in accident conditions, especially the claddings of fuel rods within the ATFC (accident-tolerant fuel cladding) concept, is an alternative and cost-effective solution, because it can be used existing zirconium claddings and their technologies manufacturing [2,3]. Various candidate materials were studied as protective coatings on zirconium alloy fuel rods, which have a lower oxidation rate in water vapor and air at temperatures of $1000 \ldots 1200^{\circ} \mathrm{C}$ [2]: $\mathrm{SiC}[3,4], \mathrm{Cr}[5,6], \mathrm{Cr}_{2} \mathrm{AlC}$ [7], CrN [8], Cr-Al [9-11], FeCrAl [12-16]. FeCrAl-based coatings can be more resistant, compared with chromium, to oxidation in water vapor at high temperatures due to the formation on the surface of a protective film of $\mathrm{Al}_{2} \mathrm{O}_{3}$ [17].

Experimental tests in water vapor at temperatures of 1200 and $1300{ }^{\circ} \mathrm{C}$ showed that ferritic iron alloys $\mathrm{FeCrAl}$, which form alumina, are superior in heat resistance to austenitic alloys of iron, which form chromium oxide at high temperatures [18]. The protective properties and structure of FeCrAl-based coatings strongly depend on their composition and deposition method [12-16]. In $\mathrm{CrAl}$ coatings, the addition of $\mathrm{Al}$ can modify the structure of the coating and affect its resistance to oxidation: high $\mathrm{Al}$ content (> 10 at.\%), promotes the formation of cubic $\gamma-\mathrm{Al}_{2} \mathrm{O}_{3}$ on the surface after high temperature oxidation, and when $\mathrm{Al}$ content is low, on the surface of the coating simultaneously forms a mixture of $\mathrm{Cr}_{2} \mathrm{O}_{3}$ and $\mathrm{Al}_{2} \mathrm{O}_{3}$ [10].

Under reactor operating conditions, the fuel element cladding material can be subjected to micro-impact (debris), as well as abrasion of the material of the spacer grids (fretting), which can lead to violation of their integrity and leakage of radioactive products into the coolant, which is unacceptable [19-21]. Studies of wear resistance of various cladding materials have shown that $\mathrm{FeCrAl}$ alloys have greater wear resistance than zirconium alloy $\mathrm{Zr}-4$ and $\mathrm{SiC} / \mathrm{SiC}$ composites due to the formation of a solid layer of chromium oxide on their surface $[22,23]$. The resistance of vacuum-arc coatings based on $\mathrm{FeCrAl}$ to micro-impact (cavitation) and abrasive erosion, depending on the deposition conditions, require additional research.

The aim of this work was to study the effect of the composition of cathodic arc coatings based on $\mathrm{Fe}, \mathrm{Cr}$ and $\mathrm{Al}$ on their structure and protective properties on $\mathrm{Zr} 1 \mathrm{Nb}$ alloy claddings.

\section{EXPERIMENTAL METHODS}

Coatings were deposited on a cathodic arc system equipped with two opposing plasma sources [24]. Alloys of $\mathrm{Fe}(99.9 \%), \mathrm{Cr}(99.9 \%), \mathrm{Al}(99.9 \%)$ and $\mathrm{CrAl}$ (60/30 wt.\%) were used as cathodes. Cathodes with a diameter of $60 \mathrm{~mm}$ were located on opposite sides of the vacuum chamber with a diameter of $0.5 \mathrm{~m}$. To obtain different concentrations of elements in the coatings the arc discharge current was varied from 60 to $120 \mathrm{~A}$ (Table 1). The coating was deposited on polished samples of stainless steel $18 \mathrm{Cr} 10 \mathrm{NiTi} \varnothing 20 \mathrm{~mm}$ and a thickness of $2 \mathrm{~mm}$, as well as fragments of fuel claddings made of $\mathrm{Zr} 1 \mathrm{Nb}$ alloy $\varnothing 9.1 \mathrm{~mm}$. The samples rotated planetary in the center of the chamber between the plasma sources at a distance of $250 \mathrm{~mm}$ from the cathodes. The speed of rotation of the samples during deposition was $\sim 30 \mathrm{rpm}$. The initial vacuum was $\sim 10^{-3} \mathrm{~Pa}$. The surface of the samples was cleaned with 
metal plasma for $3 \mathrm{~min}$ at a negative potential on the samples $-1300 \mathrm{~V}$.

Coatings were deposited in vacuum $\sim 2 \cdot 10^{-3} \mathrm{~Pa}$ for 60 min with a negative bias potential on the samples $50 \mathrm{~V}$ and a temperature of $450{ }^{\circ} \mathrm{C}$. The thickness of the coatings was $\sim(12 \pm 2) \mu \mathrm{m}$.

The chemical composition of the coatings was determined by energy dispersive X-ray spectroscopy EDS (Oxford Link ISIS 300) at $20 \mathrm{kV}$. The surface morphology and thickness of the coatings was studied using a scanning electron microscope JSM $7001 \mathrm{~F}$.

XRD analysis was performed on DRON-2.0 X-ray diffractometer in $\mathrm{Co}-\mathrm{K} \alpha$ radiation equipped with $\mathrm{Fe}$ selectively absorbing filter and scintillation detector. Qualitative phase analysis was performed using the ICDD PDF-2 database. Estimating of substructural characteristics (crystallite size $\mathbf{D}$ and microstrains $\boldsymbol{\varepsilon}$ ) of the coatings is based on the diffraction peaks broadening. The analysis was performed using Williamson-Hall method. The annealed silicon powder was taken as the standard sample to deconvolute physical and instrumental broadening.

The cavitation erosion of the samples was investigated at the stand described in [25]. The cavitation zone was formed below the end surface of the concentrator mounted in a water vessel at a distance of $(0.5 \pm 0.05) \mathrm{mm}$ from the sample surface. Cavitation erosion was determined by mass loss with an accuracy of $\pm 0.015 \mathrm{mg}$.

Abrasive wear was measured using a plane-to-disk scheme by a weighted method over a fixed period of time. The disk made of material with rigidly fixed abrasive particles rotates with a linear speed of $4.38 \mathrm{~m} / \mathrm{s}$ with a load on a flat sample of $2.2 \mathrm{~N}$. The nature of the samples surface destruction was examined using an optical microscope MMR-4.

Microhardness of the coatings was measured on a PMT-3 tester with a Vickers diamond indenter at a load of $1 \mathrm{~N}$.

The average corrosion rate in a $3 \%$ aqueous $\mathrm{NaCl}$ solution was determined using the potentiostat PI 50-1 in a standard electrochemical cell of NPP-2 at temperature of $20^{\circ} \mathrm{C}$. The anode polarization curves were obtained by changing the potential at a speed of $1 \mathrm{mV} / \mathrm{s}$. The chloride-silver electrode was used as the reference electrode, and the results are relative to the normal hydrogen electrode.

Tests for oxidation resistance of the fuel tube fragments $(\varnothing 9.1 \mathrm{~mm}, \mathrm{l}=10 \mathrm{~mm})$ of $\mathrm{Zr} 1 \mathrm{Nb}$ alloy with deposited coatings were performed by annealing in air at $1150{ }^{\circ} \mathrm{C}$ for one hour. After oxidation the samples were weighed on a laboratory balance VLR-20 with an accuracy of $\pm 0.015 \mathrm{mg}$.

\section{RESULTS AND DISCUSSION}

The results of studies of the composition of vacuumarc coatings obtained from the cathodes of $\mathrm{Fe}, \mathrm{Cr}, \mathrm{Al}$, and $\mathrm{CrAl}$, are presented in Table 1 .

As can be seen from Table 1 the composition of the deposited coatings varies from $\mathrm{FeCr}$, FeCrAl to $\mathrm{CrAl}$ depending on the type of cathodes used and the arc discharge current.

Deposition of FeCrAl coatings from two opposite plasma sources makes it possible to easily change its composition by changing the arc currents of different cathodes of known composition ( $\mathrm{Fe}$ and $\mathrm{CrAl}$ ). In addition, all coatings do not contain impurities of nitrogen and oxygen (concentration $<0.1$ at. \%), which are registered at the level of $\sim 5 \mathrm{wt} . \%$ after coatings deposition from a single alloy FeCrAl cathode [26]. In Fig. 1 SEM images of the surface of the investigated coatings of $\mathrm{FeCr}, \mathrm{FeCrAl}$, and $\mathrm{CrAl}$ systems (see Table 1) are presented.

Table 1

The concentration of elements in coatings deposited using the cathodes of $\mathrm{Fe}, \mathrm{Cr}, \mathrm{Al}$, and $\mathrm{CrAl}$

\begin{tabular}{|c|c|c|c|c|c|c|c|}
\hline \multirow{2}{*}{$\#$} & \multicolumn{3}{|c|}{ Cathode current, A } & \multicolumn{3}{c|}{ Concentration, at.\% } \\
\cline { 2 - 8 } & Fe & Cr & Al & CrAl & Fe & Cr & $\mathrm{Al}$ \\
\hline 1 & 120 & 100 & - & - & 68.5 & 31.5 & - \\
\hline 2 & 120 & 90 & - & - & 73.1 & 26.9 & - \\
\hline 3 & 120 & - & - & 90 & 63.7 & 22 & 14.3 \\
\hline 4 & 120 & - & - & 100 & 53 & 24.6 & 22.4 \\
\hline 5 & - & 120 & 60 & - & - & 86 & 14 \\
\hline
\end{tabular}

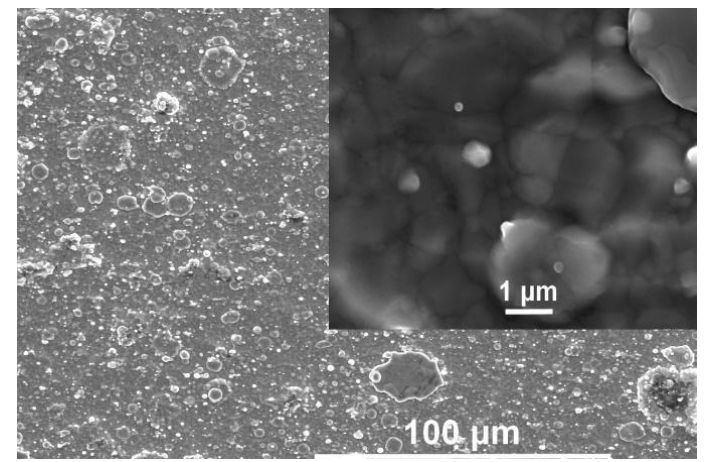

$a$
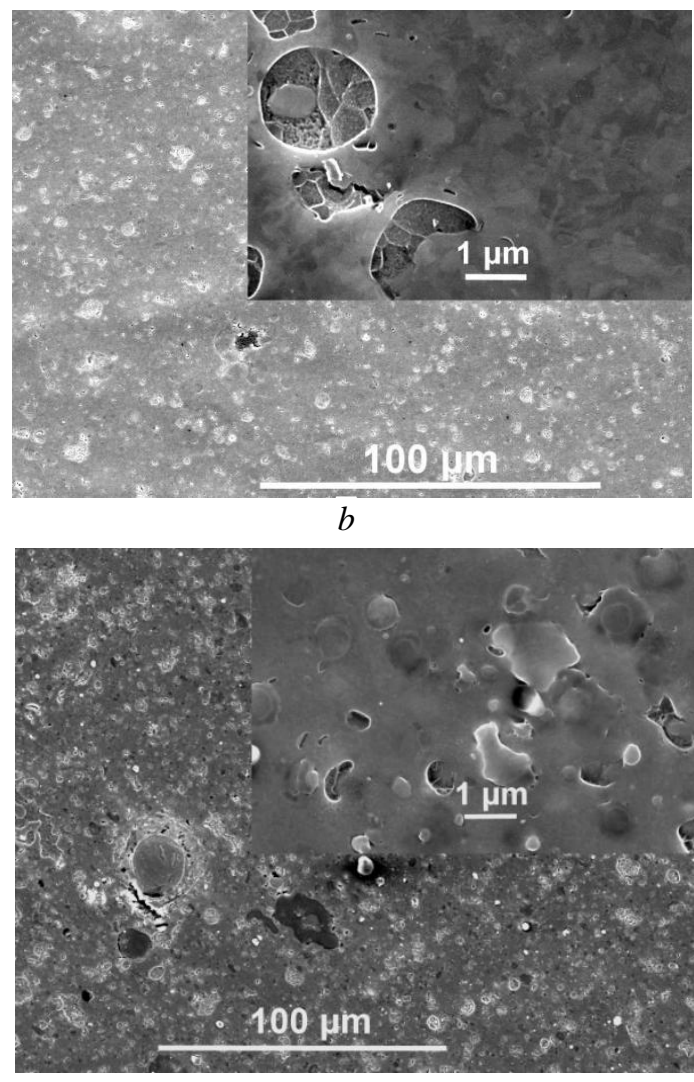

$c$

Fig. 1. SEM images of the surface of coatings: $\mathrm{FeCr} \# 1$ (a); $\mathrm{FeCr} \# 2$ (b); FeCrAl \#3 (c) 


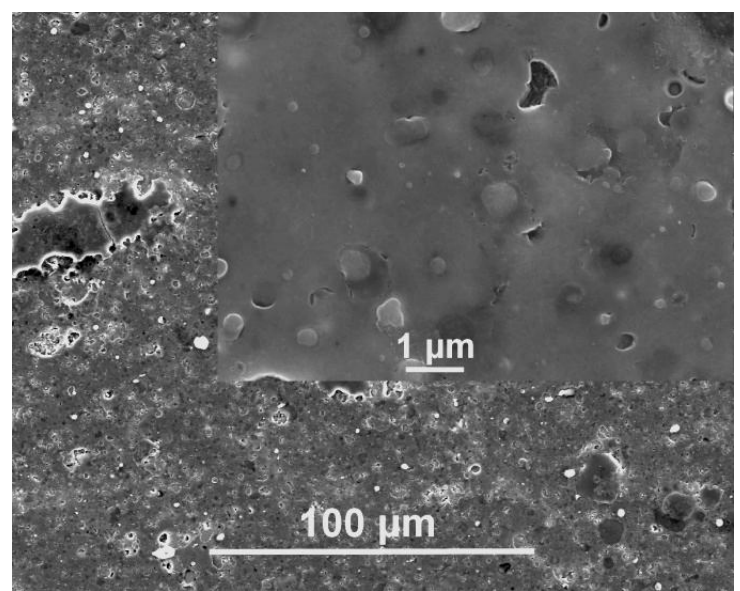

$d$

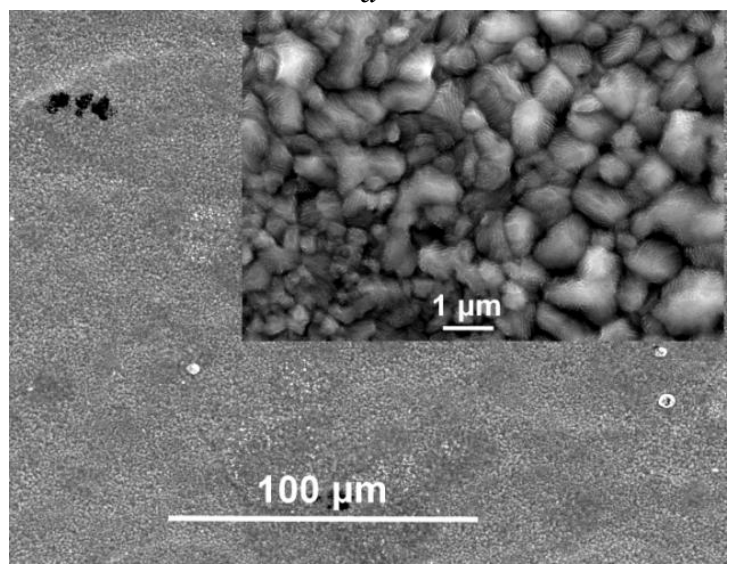

$e$

Fig. 1. SEM images of the surface of coatings: $\mathrm{FeCrAl} \mathrm{\# 4} \mathrm{(d)} \mathrm{and} \mathrm{CrAl} \# 5$ (e)

As can be seen from the images of $\mathrm{FeCr}$ coatings (\#1 and 2) a decrease in their chromium composition by 4.6 at.\% leads to a change in surface morphology: cell sizes are significantly reduced, the surface of the coatings is less developed and there are fewer macrodefects (c, d). The change in the composition of the FeCrAl coating (samples \# 3,4) in such values of the concentration of elements (see Table 1) has almost no effect on the surface morphology. The observed macro defects in the coatings can be identified as drops of cathode material [27]. The size of macroparticles on the surface of the coatings varies from some micrometers to several tens of micrometers. Such number and size of defects are observed in metal coatings deposited from an unfiltered stream of vacuum-arc plasma from cathodes with low melting point [27]. The surface of the CrAl coating (sample \#5) looks like a conglomerate of globules of micron scale, on which there are strips or "terraces" with a width of $\sim 100 \mathrm{~nm}$. This may be due to the large arc current $\sim 120$ A of chromium cathode and the effect of sputtering lighter aluminium during the coating deposition. A similar effect of the formation of the globular structure was also observed in the $\mathrm{CrAl}$ coatings $(17.08 \mathrm{wt} \% \mathrm{Al})$, which were deposited by magnetron sputtering from the target $80 \mathrm{wt} . \% \mathrm{Cr}+$ 20 wt.\% Al [11].

X-ray diffraction patterns of coatings are presented in Fig. 2.

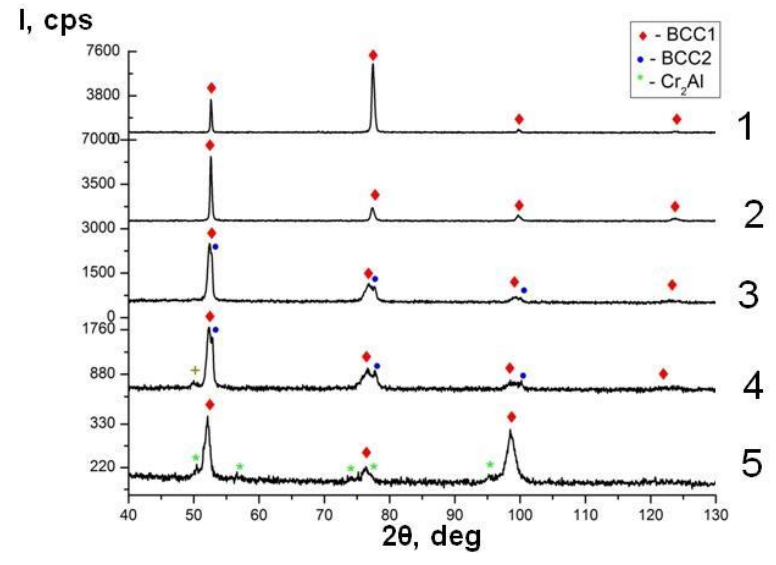

Fig. 2. Diffraction patterns of coatings: $\mathrm{FeCr}(1)$; $\mathrm{FeCr}$ (2); FeCrAl (3); FeCrAl (4), and $\mathrm{CrAl}$ (5)

According to XRD data $\mathrm{FeCr}$ coating \#1 is a singlephase (BCC lattice, solid solution based on iron and chromium). The lattice parameter of the BCC phase is equal to $a=2.8703 \AA$. The crystallite size and microstrain value of this phase were $D=181.9 \mathrm{~nm}$ and $\varepsilon=2.16 \cdot 10^{-3}$, respectively. Analysis of the intensity distribution of the peaks indicates the presence of texture (200), e.g. some grains are preferably oriented by crystallographic planes (200) parallel to the sample surface. FeCr coating \#2 with a lower chromium content is also single-phase; it contains only the BCC phase with the lattice parameter $a=2.8709 \AA$. Estimated crystallite size and microstrain value were $D=89.4 \mathrm{~nm}$ and $\varepsilon=2.93 \cdot 10^{-3}$, respectively. Intensity distribution of the diffraction peaks corresponds to the non-textured state.

Two phases were observed in the $\mathrm{FeCrAl}$ coating \#3: BCC1 and BCC2 (both phases have a BCC lattice, but differ in lattice parameters and substructural characteristics). The lattice parameter of the BCC1 phase was equal to $a=2.8790 \AA$; the crystallite size and microstrain were $D=23.9 \mathrm{~nm}$ and $\varepsilon=3.01 \cdot 10^{-3}$, respectively. The lattice parameter of the BCC2 phase was equal to $a=2.859 \AA$; the crystallite size and microstrain were $D=163.2 \mathrm{~nm}$ and $\varepsilon=1.1 \cdot 10^{-3}$, respectively. The intensity distribution of the peaks of both phases corresponds to the non-textured state. Phase composition of the coating $\mathrm{FeCrAl} \mathrm{\# 4} \mathrm{(with} \mathrm{a} \mathrm{higher}$ concentration of aluminum) was similar to the coating of $\mathrm{FeCrAl} \mathrm{\# 3.} \mathrm{The} \mathrm{lattice} \mathrm{parameter} \mathrm{of} \mathrm{the} \mathrm{BCC} 1$ phase was equal to $a=2.8851 \AA$; the crystallite size and microstrain were $D=17.5 \mathrm{~nm}$ and $\varepsilon=3.62 \cdot 10^{-3}$. The lattice parameter of the $\mathrm{BCC} 2$ phase was equal to $a=2.861 \AA$, the substructural characteristics of this phase were not determined. The intensity distribution of the peaks of both phases corresponds to the nontextured state. It should be noted that additional weak peak was observed in the diffraction pattern (at an angle of $2 \theta \approx 50.05^{\circ}$ ). This indicates the presence of another phase in the coating, but it could not be identified.

Two phases were detected in the coating $\mathrm{CrAl} \# 5$ : BCC (solid solution with BCC lattice) and $\mathrm{Cr}_{2} \mathrm{Al}$ (tetragonal system, space group \#139). The lattice parameter of the BCC phase was equal to $a=2.892 \AA$; the crystallite size and microstrain were $D=16.8 \mathrm{~nm}$ and $\varepsilon=8.1 \cdot 10^{-4}$, respectively. The lattice parameters of 
the $\mathrm{Cr}_{2} \mathrm{Al}$ phase are: $a=2.978 ; c=8.621 \AA$, the substructural characteristics of this phase were not determined. The results of XRD analysis of structural characteristics for all coatings are further summarized in Table 2.

Table 2

Phase composition and structural characteristics (lattice parameters, $D$ - crystallite size and $\boldsymbol{\varepsilon}$ - microstrain) of coatings with different composition (see Table 1)

\begin{tabular}{|c|c|c|c|c|}
\hline$\#$ & Phase & Lattice parameters, $\AA$ & $\mathbf{D}, \mathbf{n m}$ & $\mathbf{\varepsilon , \mathbf { 1 0 } ^ { - 3 }}$ \\
\hline 1 & $\mathrm{BCC}$ & 2.8703 & 181.9 & 2.16 \\
\hline 2 & $\mathrm{BCC}$ & 2.8709 & 89.4 & 2.93 \\
\hline \multirow{2}{*}{3} & $\mathrm{BCC} 1$ & 2.8790 & 23.9 & 3.01 \\
\cline { 2 - 5 } & $\mathrm{BCC} 2$ & 2.859 & 163.2 & 1.10 \\
\hline \multirow{2}{*}{4} & $\mathrm{BCC} 1$ & 2.8851 & 17.5 & 3.62 \\
\cline { 2 - 5 } & $\mathrm{BCC} 2$ & 2.861 & - & - \\
\hline \multirow{2}{*}{5} & $\mathrm{BCC}$ & 2.892 & 16.8 & 0.81 \\
\cline { 2 - 5 } & $\mathrm{Cr}_{2} \mathrm{Al}$ & $a=2.978 ; c=8.621$ & - & - \\
\hline
\end{tabular}

Thus, in the deposited coatings, the single-phase state is realized only for coatings of the $\mathrm{FeCr}$ system; and two-phase structure is formed for coatings in which aluminum is present. In the coatings of the $\mathrm{FeCrAl}$ system \#3 and 4, which were deposited from two Fe and $\mathrm{CrAl}$ cathodes, 2 phases were identified: $\mathrm{BCC} 1$ and BCC2 with crystallites sizes smaller than in the coatings previously synthesized from single $\mathrm{FeCrAl}$ cathode [26]. The lowest microstrain value is observed in $\mathrm{CrAl}$ coatings.

Typical kinetic curves of erosion of the studied coatings on the time of cavitation wear are shown in Fig. 3. As can be seen from Fig. 3, among of all the studied coatings $\mathrm{FeCr}$ coatings are destroyed the fastest under the action of cavitation, regardless of the chromium concentration. FeCrAl coatings have more than three times lower erosion rates, regardless of the aluminum concentration. The lowest rate of destruction has a coating of $\mathrm{CrAl}$, the surface of which, as can be seen from Fig. 1, consists of globules of micron scale.

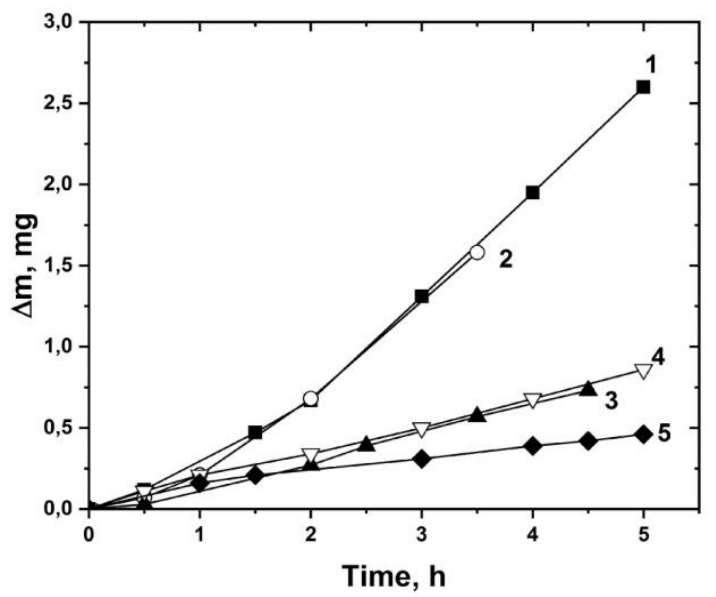

Fig. 3. Coatings mass loss depending on the time of cavitation wear: $\mathrm{FeCr}(1,2) ; \mathrm{FeCrAl}(3,4)$, and $\mathrm{CrAl}(5)$

The Fig. 4 presents the test results of the investigated coatings for abrasive wear.

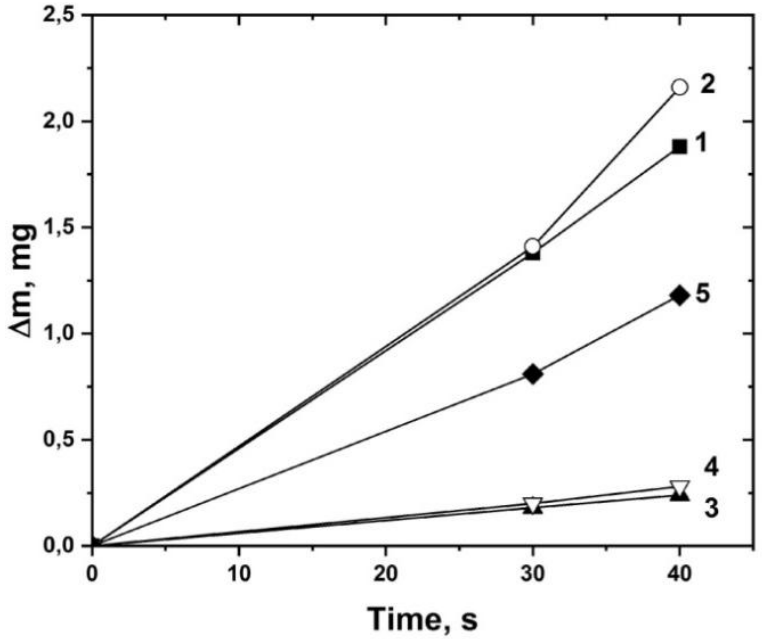

Fig. 4. Coatings mass loss depending on the time of abrasive wear: $\mathrm{FeCr}(1,2) ; \mathrm{FeCrAl}(3,4)$, and $\mathrm{CrAl}(5)$

The FeCr coating loses a weight of $\sim 2 \mathrm{mg}$ in $40 \mathrm{~s}$ of the test (\#1), and the coating with lower chromium content loses $0.25 \mathrm{mg}$ more (\#2). The intermediate position is held by $\mathrm{CrAl}$ coating (\#5), which reduces its weight by $1.2 \mathrm{mg}$. The most resistant to abrasive wear under friction conditions are FeCrAl coatings (\#3, 4), which, regardless of the composition, lose 8 times less $0.25 \mathrm{mg}$ during the same test period.

Table 3 shows the mechanical characteristics of coatings. The cavitation and abrasive wear rates for coatings were calculated from the kinetic curves shown in Figs. 3, 4.

Table 3

Mechanical characteristics of coatings

$\left(H \mu-\right.$ microhardness; $v_{k}-$ cavitation and $v_{a}$ - abrasive wear rate)

\begin{tabular}{|c|c|c|c|c|c|}
\hline \multirow{2}{*}{ Parameter } & \multicolumn{5}{|c|}{ Sample \# } \\
\cline { 2 - 6 } & 1 & 2 & 3 & 4 & 5 \\
\hline$H \mu, \mathrm{GPa}$ & $4.2 \pm 0.2$ & $4.4 \pm 0.2$ & $9.4 \pm 0.3$ & $9.9 \pm 0.3$ & $9.3 \pm 0.3$ \\
\hline$v_{k}, \mathrm{mg} / \mathrm{h}$ & 0.52 & 0.45 & 0.16 & 0.17 & 0.1 \\
\hline$v_{a}, \mathrm{mg} / \mathrm{h}$ & 169.2 & 194.4 & 21.6 & 25.2 & 106.2 \\
\hline
\end{tabular}

As can be seen from Table 3 microhardness of $68.5 \mathrm{Fe}-31.5 \mathrm{Cr}$ and $73 \mathrm{Fe}-27 \mathrm{Cr}$ coatings are at the level of 4.2 and $4.4 \mathrm{GPa}$, respectively. The cavitation $(0.52$ and $0.45 \mathrm{mg} / \mathrm{h}$ ) and abrasive (169 and $194 \mathrm{mg} / \mathrm{h}$ ) wear rates for these coatings are also quite close. Alloying of this system with aluminum in the amount of 14.3 at.\% leads to a significant increase in the microhardness of coatings to $9.4 \mathrm{GPa}$ and reduces the rate of their cavitation and abrasive wear to 0.16 and $22 \mathrm{mg} / \mathrm{h}$, respectively. A further increase in the aluminum content to 22.4 at. $\%$ increases the microhardness of $\mathrm{FeCrAl}$ coatings to $9.9 \mathrm{GPa}$, but at the same time, slightly reduces the resistance to cavitation and abrasive wear. $\mathrm{FeCrAl}$ coatings deposited from two $\mathrm{Fe}$ and $\mathrm{CrAl}$ cathodes significantly exceed the cavitation resistance of zirconium alloys $\mathrm{Zr} 1 \mathrm{Nb}$ and $\mathrm{Zr} 2.5 \mathrm{Nb}$, for which the cavitation wear rates are 0.8 and $0.6 \mathrm{mg} / \mathrm{h}$, respectively [28]. Also, these coatings are more resistant to cavitation than FeCrAl coatings, which were deposited from a single cathode (cavitation wear rate $0.3 \ldots 1.6 \mathrm{mg} / \mathrm{h})[26]$. 
CrAl coatings also have high microhardness $(9.3 \mathrm{GPa})$ and the lowest cavitation wear rate $(0.1 \mathrm{mg} / \mathrm{h})$ of all studied coatings. However, despite the relatively high microhardness of these coatings, their resistance to abrasion is 5 times lower than that of $\mathrm{FeCrAl}$ coatings. Thus, the best mechanical properties have $\mathrm{FeCrAl}$ coatings of both compositions, with a slight advantage of the sample \#3.

In order to determine the influence of the parameters of the deposition process on the corrosion resistance of coatings, their study was carried out by potentiometry. Polarization curves of coatings in $3 \% \mathrm{NaCl}$ solution are shown in Fig. 5.

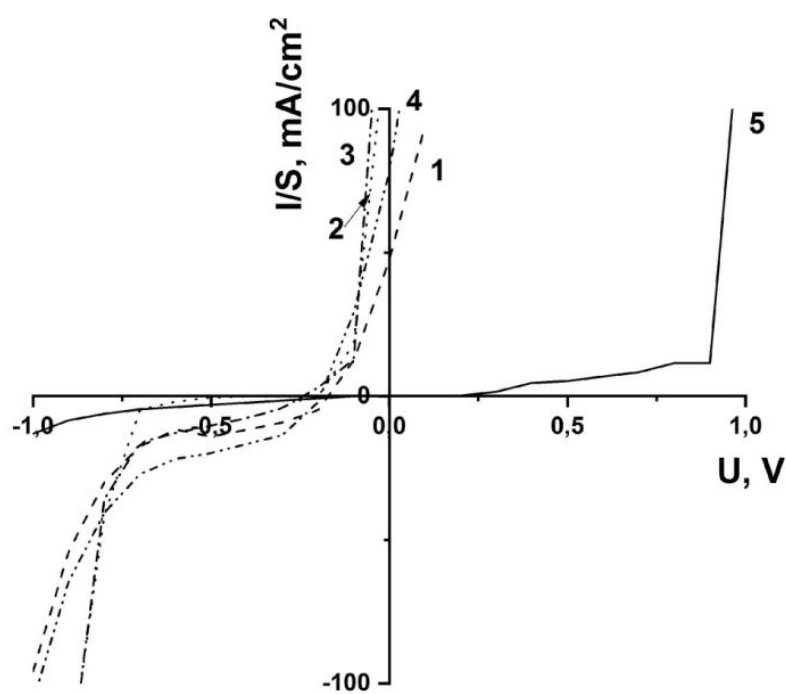

Fig. 5. Polarization curves of coatings $\mathrm{FeCr}(1,2)$; $\mathrm{FeCrAl}(3,4)$, and $\mathrm{CrAl}(5)$ in a solution of $3 \% \mathrm{NaCl}$
Analysis of the polarization curves (see Fig. 5) shows that the potential for the onset of corrosion dissolution ( $\varphi$ n) takes values for coatings \#1-5, respectively: $-0.179 ;-0.3 ;-0.25 ;-0.2 ;+0.05 \mathrm{~V}$. It is seen that the values of $\varphi$ nk for coatings \#1-4 are close and negative, and for \#5 it differs significantly and is shifted to the positive region, which indicates a higher corrosion resistance of $\mathrm{CrAl}$ coating. Thus, coatings containing iron with a concentration of from 53 to $73 \mathrm{wt} . \%$ have almost the same corrosion resistance.

In order to determine the effect of the composition of the coatings on the resistance to oxidation of the $\mathrm{Zr} 1 \mathrm{Nb}$ alloy cladding, they were annealed in an air atmosphere at a temperature of $T=1150{ }^{\circ} \mathrm{C}$ for one hour.

On the photos (Table 4) it can be seen how $\mathrm{Zr} 1 \mathrm{Nb}$ tube without coating is deformed and changes the colour of the surface from metallic to white with brown spots due to the formation of the oxide layer after oxidation. At the same time, coated tubes are deformed much less and only due to the inner unprotected surface and have a green, red or black colour of the oxide layer, depending on the elemental composition of the coating. This surface colour of the protective coatings after oxidation may indicate the formation of chromium-based oxides in the surface layer. All deposited coatings of $\mathrm{FeCr}$, $\mathrm{FeCrAl}$ and $\mathrm{CrAl}$ significantly increase the resistance to oxidation in air of $\mathrm{Zr} 1 \mathrm{Nb}$ alloy samples at a temperature of $1150{ }^{\circ} \mathrm{C}$ for $60 \mathrm{~min}$. After testing, the weight gain of coated tubes $\left(1.7 \ldots 5 \mathrm{mg} / \mathrm{cm}^{2}\right)$ is an order of magnitude less than that of uncoated tubes $\left(31 \mathrm{mg} / \mathrm{cm}^{2}\right)$, which indicates a high resistance to oxidation of all studied coatings, the best of which by mass gain $-\mathrm{FeCr}$.

Table 4

Photos and mass gain of the $\mathrm{Zr} 1 \mathrm{Nb}$ alloy cladding fragments after oxidation in air at a temperature of $1150{ }^{\circ} \mathrm{C}$ for $60 \mathrm{~min}$ : uncoated, with protective coatings $\mathrm{FeCr}(1,2) ; \mathrm{FeCrAl}(3,4)$, and $\mathrm{CrAl}(5)$

\begin{tabular}{|c|c|c|c|c|c|c|}
\hline Sample \# & Zr1Nb & 1 & 2 & 3 & 4 & 5 \\
\hline Initial & & & & & & \\
\hline
\end{tabular}

Studies by scanning electron microscopy and microprobe elemental analysis showed that in the coatings after oxidation forms thin $\sim 3 \ldots 5 \mu \mathrm{m}$ dense oxide layers of complex elemental composition, and on the zirconium alloy a porous oxide layer $\mathrm{ZrO}_{2}$ is formed with the thickness of $\sim 150 \mu \mathrm{m}$, which does not provide protection of the tube. Table 5 presents the SEM images 
of the cross sections of the fragments of the fuel tubes before and after oxidation.

As can be seen from Table 5 uncoated zirconium tube was oxidized outside and inside to a depth of more than $150 \mu \mathrm{m}$. FeCr coatings on samples \#1 and 2 were oxidized to a depth of $\sim 2 \mu \mathrm{m}$, and at the interface between the coating and the tube we see the mutual diffusion of the elements. A similar pattern is observed for the $\mathrm{FeCrAl}$ coating (sample \#3), and with a decrease in the composition of the $\mathrm{FeCrAl}$ coating of iron and an increase in aluminum (sample \#4), the diffusion layer is clearly not isolated. The $\mathrm{FeCrAl}$ coating is oxidized to a depth of $\sim \mu \mathrm{m}$. On the section of sample \#5 with CrAl coating, no oxidation outside the tube or diffusion of elements at the interface between the coating and the tube is recorded. This corresponds to the photograph of sample \#5, which shows changes only at the ends of the tube (see Table 4).

The elemental composition (at.\%) of the coatings after oxidation at a depth of $\sim 3 \ldots 4 \mu \mathrm{m}$ according to microprobe analysis is: $\mathrm{FeCr} \# 1-\mathrm{Fe}_{60} \mathrm{Cr}_{37} \mathrm{O}_{3}$; $\mathrm{FeCr} \# 2-$

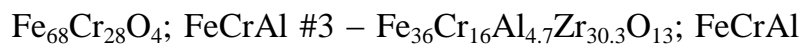
$\# 4$ - $\mathrm{Fe}_{54} \mathrm{Cr}_{31} \mathrm{Al}_{11.7} \mathrm{Zr}_{2} \mathrm{O}_{1.3}$; CrAl \#5 - $\mathrm{Cr}_{52} \mathrm{Al}_{6.5} \mathrm{O}_{41.5}$. These data confirm the analysis of electron microscopic images of sections of coated tubes. High resistance to oxidation in air and in the water vapor steam of $\mathrm{FeCr}$ alloys with a chromium concentration of more than $25 \%$ is known [29], and for coatings on zirconium alloys has not yet been studied. The obtained data indicate a fairly high resistance to oxidation of deposited $\mathrm{FeCr}$ $(26.9 \ldots 31.5 \%)$ coatings, but the problem of the predominant diffusion of iron into the zirconium alloy remains.

Table 5

SEM images of cross sections of the $\mathrm{Zr} 1 \mathrm{Nb}$ alloy cladding fragments before and after oxidation at a temperature of $1150^{\circ} \mathrm{C}, 60 \mathrm{~min}$

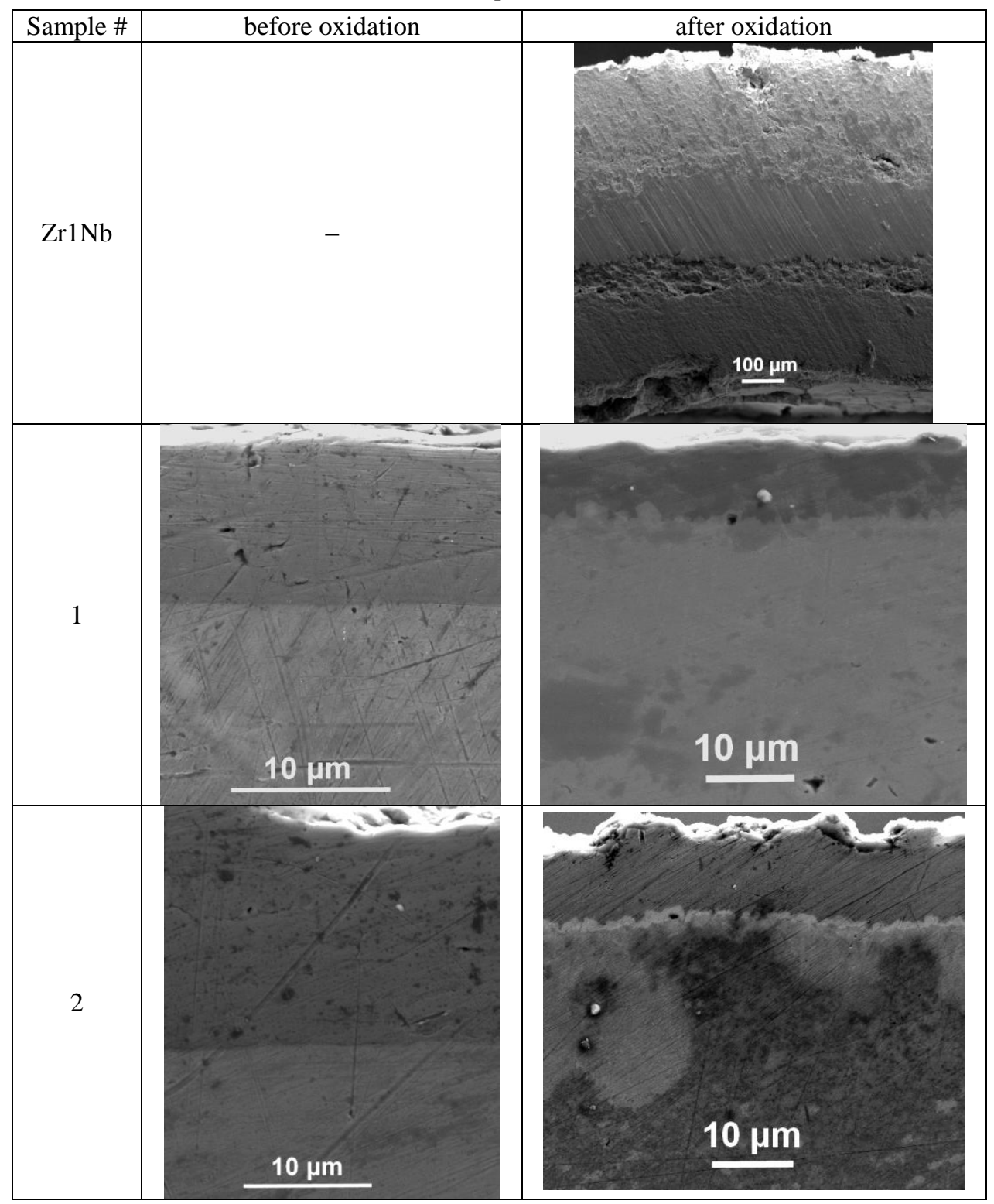




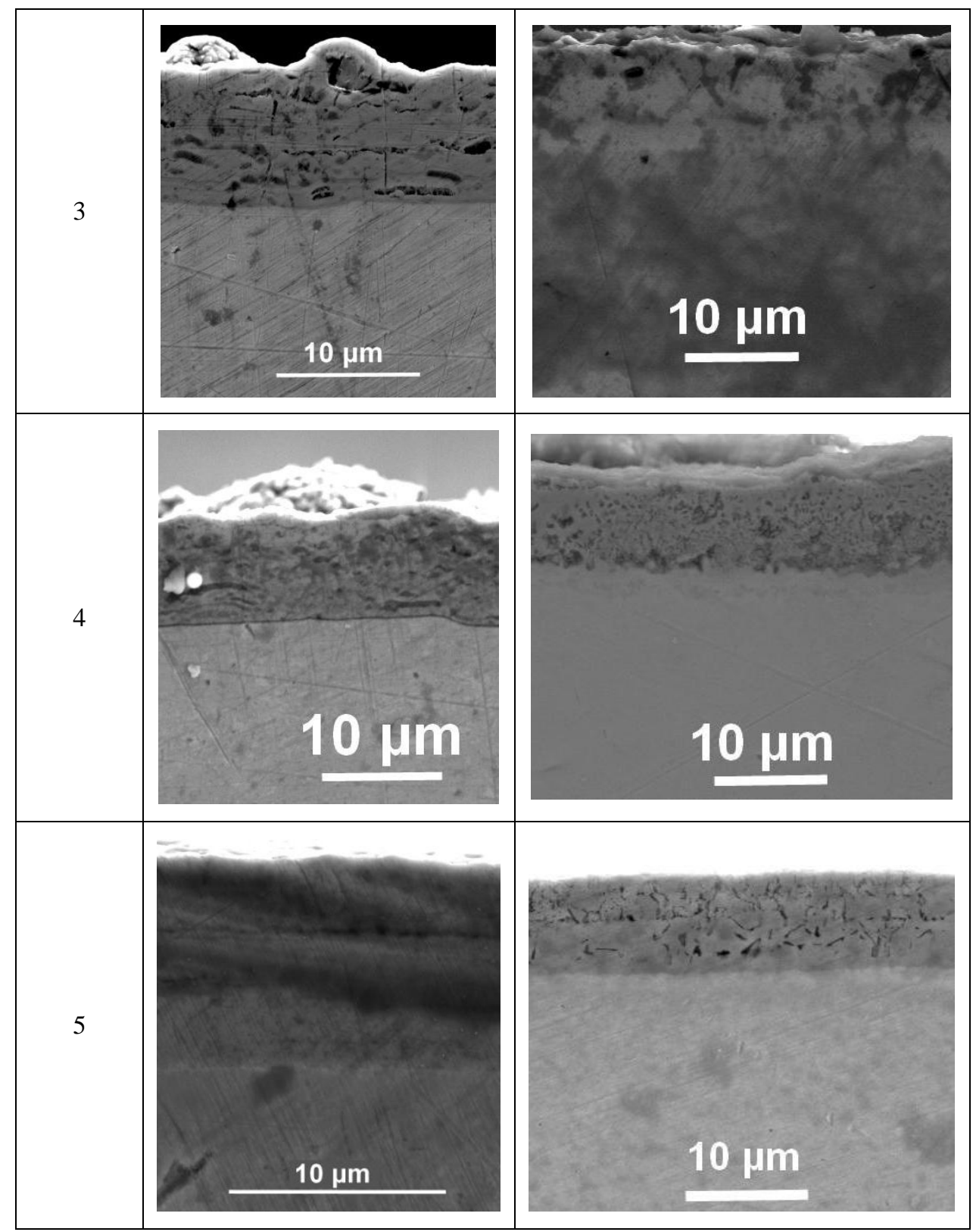

For $\mathrm{FeCrAl}$ coatings, high protective properties are also confirmed, but zirconium diffuses from the substrate in both coatings. Moreover, for the alloy $\mathrm{FeCrAl} \# 3$ in which the initial concentration of aluminum is much lower, the concentration of zirconium in the coating after oxidation is 15 times greater (30 at.\%) than in the alloy $\mathrm{FeCrAl}(\# 4)$. The effect of mutual diffusion of $\mathrm{FeCrAl}$ alloys and zirconium alloys with the formation of $\mathrm{Zr}_{2} \mathrm{Fe}$ and $\mathrm{Zr}_{3} \mathrm{Fe}$ phases was observed at different temperatures [11, 12]. The solution to this problem is possible by applying a special sublayer, which should act as a diffusion barrier between the coating and the zirconium cladding, such as molybdenum.

Scanning electron microscopy was used to study the morphology and structure of oxide layers formed after oxidation on the surface of coatings that were deposited on fragments of fuel claddings (Fig. 6). On the surface of $\mathrm{FeCr}$ coatings, very similar oxide crystals with dimensions of $0.5 \ldots 1 \mu \mathrm{m}$ are formed. In the structure of oxides on the surface of FeCrAl coatings, needle crystallites with sizes up to $1 \mu \mathrm{m}$ in length and about $100 \mathrm{~nm}$ in width are added to spinel crystals, and the most dense and homogeneous oxide crystals with sizes $<1 \mu \mathrm{m}$ are formed on the surface of $\mathrm{CrAl}$ coatings.

According to the measurements of the elemental composition from the surface of the oxide layers, they have the following composition for coatings: $\mathrm{FeCr} \# 1-$ $\mathrm{Fe}_{6} \mathrm{Cr}_{33} \mathrm{O}_{61} ; \mathrm{FeCr} \# 2-\mathrm{Fe}_{7} \mathrm{Cr}_{27} \mathrm{O}_{66} ; \mathrm{FeCrAl} \# 3$ $\mathrm{Fe}_{14} \mathrm{Cr}_{12} \mathrm{Al}_{23} \mathrm{O}_{51} ; \mathrm{FeCrAl} \# 4-\mathrm{Fe}_{10} \mathrm{Cr}_{10} \mathrm{Al}_{35} \mathrm{O}_{45} ; \mathrm{CrAl}$ $\# 5-\mathrm{Cr}_{34} \mathrm{Al}_{2} \mathrm{O}_{64}$. From these data it can be concluded that chromium oxide doped with a small amount of $\mathrm{Fe}$ $(6 . .7$ at.\%) or $\mathrm{Al}$ (2 at.\%), respectively, is formed on the surface of $\mathrm{FeCr}$ and $\mathrm{CrAl}$ coatings. Complex-alloyed spinels are formed only on the surface of FeCrAl coatings. The elemental composition of the oxide layers explains the similarity of the morphology of the oxidized surface of $\mathrm{FeCr}$ and $\mathrm{CrAl}$ coatings, and the difference between them and the morphology of the surface of $\mathrm{FeCrAl}$ coatings. 


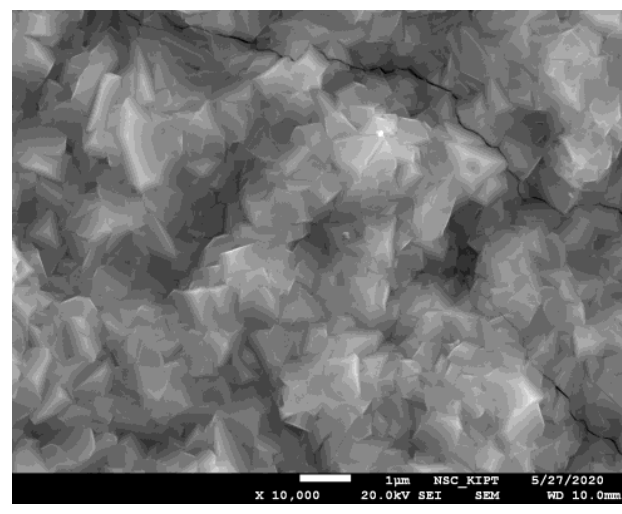

$a$

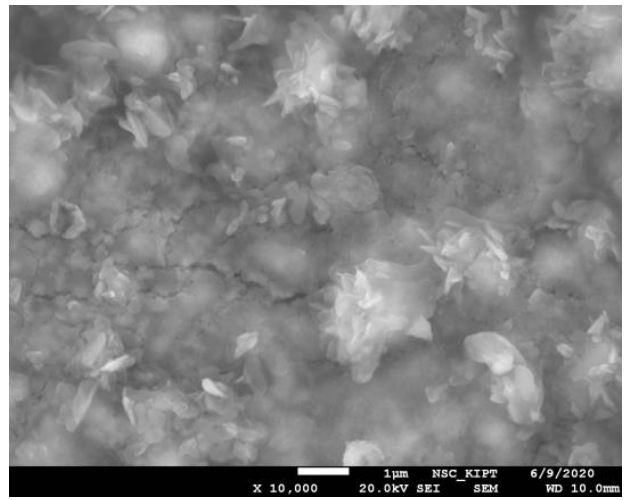

c

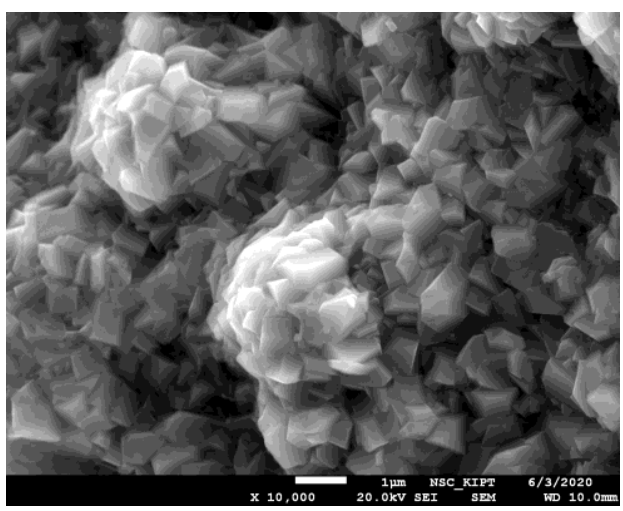

b

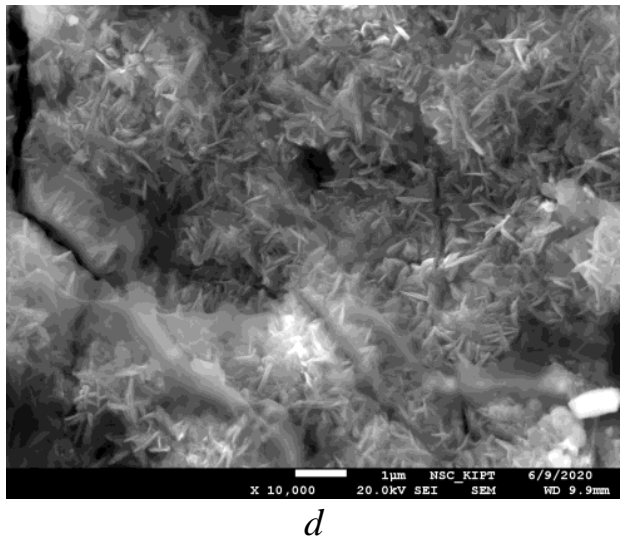

$d$

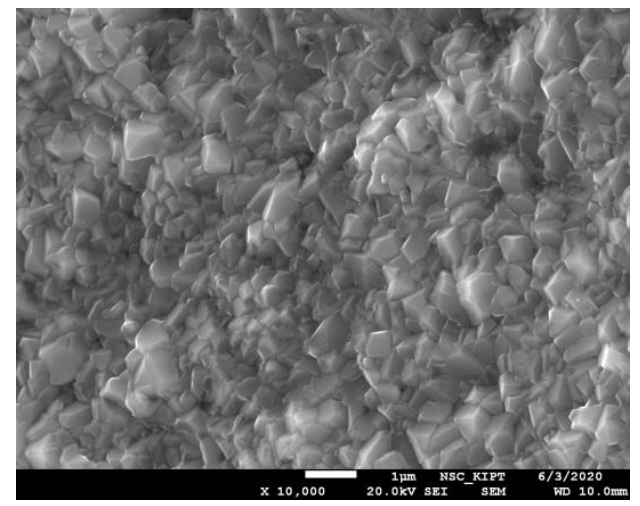

$e$

Fig. 6. SEM image of the surface of the claddings coated with $\mathrm{FeCr \# 1} \mathrm{(a);} \mathrm{FeCr \# 2} \mathrm{(b);} \mathrm{FeCrAl} \mathrm{\# 3} \mathrm{(c);}$ $\mathrm{FeCrAl} \mathrm{\# 4} \mathrm{(d),} \mathrm{and} \mathrm{CrAl} \mathrm{\# 5} \mathrm{(e)} \mathrm{after} \mathrm{oxidation} \mathrm{at} \mathrm{a} \mathrm{temperature} \mathrm{of} 1150^{\circ} \mathrm{C}, 60 \mathrm{~min}$

\section{CONCLUSIONS}

Protective coatings with different compositions of $\mathrm{Fe}, \mathrm{Cr}$, and $\mathrm{Al}$ were deposited by cathodic arc evaporation method on fragments of $\mathrm{Zr} 1 \mathrm{Nb}$ alloy fuel claddings.

In deposited coatings, the single-phase state is realized only for coatings of the $\mathrm{FeCr}$ system. For coatings in which aluminum is present, a two-phase structure is formed. In the coatings of the $\mathrm{FeCrAl}$ system \#3 and 4, which were deposited from $\mathrm{Fe}$ and $\mathrm{CrAl}$ cathodes, two BCC phases were identified. The lowest value of microstrain is observed in $\mathrm{CrAl}$ coatings.

All coatings protect the zirconium alloy from oxidation in air for an hour at a temperature of $1150^{\circ} \mathrm{C}$, forming on the surface of complex oxides with a thickness of $3 \ldots 5 \mu \mathrm{m}$.

The deposited $\mathrm{FeCrAl}$ coatings have an order of magnitude higher resistance to cavitation and 4 times higher microhardness $(H \mu=9.4 \ldots 9.9 \mathrm{GPa})$ than the FeCrAl coating obtained using a single alloy cathode. Increase in the composition of the $\mathrm{FeCrAl}$ aluminum coating from 14 to 22 at.\% leads to an increase in microhardness by $5 \%$ and a slight decrease in resistance to abrasive and cavitation wear

The optimal combination of mechanical properties and high resistance to oxidation from a series of investigated coatings $\mathrm{FeCr}, \mathrm{FeCrAl}$, and $\mathrm{CrAl}$ have $\mathrm{FeCrAl}$ system coatings with $\mathrm{Cr} \sim 22$ at. $\%$ and $\mathrm{Al}$ $\sim 14.3$ at. $\%$.

\section{REFERENCES}

1. S.J. Zinkle, K.A. Terrani, J.C. Gehin, L.J. Ott, L.L. Snead. Accident tolerant fuels for LWRs: a perspective // Journal of Nuclear Materials. 2014, v. 448 (1), p. 374-379. 
2. K.A. Terrani. Accident tolerant fuel cladding development: Promise, status, and challenges // Journal of Nuclear Materials. 2018, v. 501, p. 13-30.

3. S.L. Chen, X.J. He, C.X. Yuan. Recent studies on potential accident-tolerant fuel-cladding systems in light water reactors // Nuclear Science and Techniques. 2020, 31:32, https://doi.org/10.1007/s41365-020-0741-9.

4. J.-Y. Park, I.-H. Kim, Y.-I. Jung, H.-G. Kim, D.-J. Park, W.-J. Kim. Long-term corrosion behavior of CVD SiC in $360^{\circ} \mathrm{C}$ water and $400{ }^{\circ} \mathrm{C}$ steam // Journal of Nuclear Materials. 2013, v. 443 (1), p. 603-607.

5. J.-H. Park, H.-G. Kim, J.-y. Park, Y.-I. Jung, D.-J. Park, Y.-H. Koo. High temperature steamoxidation behavior of arc ion plated $\mathrm{Cr}$ coatings for accident tolerant fuel claddings // Surf. Coat. Technol. 2015 , v. 280 , p. $256-259$.

6. A.S. Kuprin, V.A. Belous, V.V. Bryk, R.L. Vasilenko, V.N. Voyevodin, V.D. Ovcharenko, G.N. Tolmachova, I.V. Kolodiy, V.M. Lunyov, I.O. Klimenko. Vacuum-arc chromium coatings for $\mathrm{Zr}-1 \mathrm{Nb}$ alloy protection against high-temperature oxidation in air // Problems of Atomic Science and Technology. 2015, N 2(96), p. 111-118.

7. S. Mráz, M. Tyra, M. Baben, M. Hans, X. Chen, F. Herrig, K. Lambrinou, J.M. Schneider. Thermal stability enhancement of $\mathrm{Cr}_{2} \mathrm{AlC}$ coatings on $\mathrm{Zr}$ by utilizing a double layer diffusion barrier // Journal of the European Ceramic Society. 2020, v. 40, p. 11191124.

8. C. Meng, L. Yang, Y. Wu, J. Tan, W. Dang, X. He, X. Ma. Study of the oxidation behavior of CrN coating on $\mathrm{Zr}$ alloy in air // Journal of Nuclear Materials. 2019, v. 515, p. 354-369.

9. D.J. Park, Y.I. Jung, J.H. Park, Y.H. Lee, B.K. Choi, H.G. Kim. Microstructural characterization of accident tolerant fuel cladding with $\mathrm{Cr}$-Al alloy coating layer after oxidation at $1200{ }^{\circ} \mathrm{C}$ in a steam environment // Nuclear Engineering and Technology. 2020, v. 52(10), p. 2299-2305.

10. W. Zhong, P.A. Mouche, B.J. Heuser. Response of $\mathrm{Cr}$ and $\mathrm{Cr}-\mathrm{Al}$ coatings on zircaloy-2 to high temperature steam // Journal of Nuclear Materials. 2018, v. 498, p. 137-148.

11. H.H. Son, N. Kim, S.J. Kim. Nano/microscale roughness control of accident-tolerant $\mathrm{Cr}$ - and $\mathrm{CrAl}-$ coated surfaces to enhance critical heat flux // Applied Thermal Engineering. 2020, v. 167, p. 114786.

12. D.J. Park, H.G. Kim, J.Y. Park, Y.I. Jung, J.H. Park, Y.H. Koo. A study of the oxidation of FeCrAl alloy in pressurized water and high-temperature steam environment // Corrosion Science. 2015, v. 94, p. 459465.

13. X. Han, Y. Wang, S. Peng, H. Zhang. Oxidation behavior of $\mathrm{FeCrAl}$ coated Zry-4 under high temperature steam environment // Corrosion Science. 2019, v. 149, p. 45-53.

14. J.G. Gigax, M. Kennas, H. Kim, B.R. Maier, H. Yeom, G.O. Johnson, K. Sridharan, L. Shao Interface reactions and mechanical properties of FeCrAl-coated Zircaloy-4 // Journal of Nuclear Materials. 2019, v. 519, p. 57-63.

15. D. Park, P.A. Mouche, W. Zhong, K.K. Mandapaka, G.S. Was, B.J. Heuser. TEM/STEM study of
Zircaloy-2 with protective $\mathrm{FeAl}(\mathrm{Cr})$ layers under simulated BWR environment and high-temperature steam exposure // Journal of Nuclear Materials. 2018, v. 502, p. 95-105.

16. M. Kennas, H. Kim, J.G. Gigax, T. Wang, B.R. Maier, H. Yeom, G.O. Johnson, T. Dabney, K. Sridharan, K.L. Peddicord, L. Shao. Radiation response of FeCrAl-coated Zircaloy-4 // Journal of Nuclear Materials. 2020, v. 536, p. 152175.

17. K.A. Terrani, S.J. Zinkle, L.L. Snead. Advanced oxidation-resistant iron-based alloys for LWR fuel cladding // Journal of Nuclear Materials. 2014, v. 448, p. $420-435$.

18. K.A. Terrani, C.M. Parish, D. Shin, B.A. Pint. Protection of zirconium by alumina-and chromiaforming iron alloys under high-temperature steam exposure // Journal of Nuclear Materials. 2013, v. 438(1), p. 64-71.

19. H.K. Kim, Y.H. Lee, S.P. Heo. Mechanical and experimental investigation on nuclear fuel fretting // Tribology International. 2006, v. 39, p. 1305-1319.

20. Y.H. Lee, T.S. Byun. A comparative study on the wear behaviors of cladding candidates for accidenttolerant fuel // Journal of Nuclear Materials. 2015, v. 465 , p. $857-865$.

21. Z. Cai, Z. Li, M. Yin, M. Zhu, Z. Zhou. A review of fretting study on nuclear power equipment // Tribology International. 2020, v. 144, p. 106095.

22. T.C. Winter, R.W. Neu, P.M. Singh, L.E. Kolaya, C.S. Deo. Fretting wear comparison of cladding materials for reactor fuel cladding application // Journal of Nuclear Materials. 2018, v. 508, p. 505515.

23. T. Winter, R.W. Neu, P.M. Singh, L.E. Kolaya, D. Vizoso, C.S. Deo. Coefficient of friction evolution with temperature under fretting wear for $\mathrm{FeCrAl}$ fuel cladding candidate // Journal of Nuclear Materials. 2019, v. 520, p. $140-151$.

24. B. Warcholinski, A. Gilewicz, O. Lupicka, A.S. Kuprin, G.N. Tolmachova, V.D. Ovcharenko, I.V. Kolodiy, M. Sawczak, A.E. Kochmanska, P. Kochmanski, T.A. Kuznetsova, T.I. Zubar, A.L. Khudoley, S.A. Chizhik. Structure of CrON coatings formed in vacuum arc plasma fluxes // Surface and Coatings Technology. 2017, v. 309, p. 920-930.

25. V.G. Marinin, V.I. Kovalenko, N.S. Lomino, Yu.A. Zadneprovsky, V.D. Ovcharenko. Cavitation erosion of $\mathrm{Ti}$ coatings produced by the vacuum arc method // International Symposium on Discharges and Electrical Insulation in Vacuum, ISDEIV, 2000, v. 2, p. $567-570$

26. V.A. Belous, M.A. Bortnitskaya, R.L. Vasilenko, V.N. Voyevodin, I.O. Klimenko, V.I. Kovalenko, I.V. Kolodiy, A.S. Kuprin, V.G. Marinin, V.D. Ovcharenko, M.A. Tikhonovsky. Structure and properties of coatings based on FeCrAl and Cr18Ni10T // Problems of Atomic Science and Technology. 2020, N 2(126), p. 125-131.

27. E. Dobruchowska, A. Gilewicz, B. Warcholinski, L. Libralesso, D. Batory, L. Szparaga, D. Murzynski, J. Ratajski. Al-Mn based coatings deposited by cathodic arc evaporation for corrosion protection of 
AISI 4140 alloy steel // Surface and Coatings Technology. 2019, v. 362, p. 345-354.

28. I.V. Kolodiy, V.A. Belous, M.A. Bortnitskaya, R.L. Vasilenko, V.N. Voyevodin, V.I. Kovalenko, A.S. Kuprin, V.G. Marinin, V.D. Ovcharenko, G.Y. Rostova, P.I. Stoev, M.A. Tikhonovsky, G.N. Tolmachova. Structure, mechanical characteristics, oxidation and cavitation resistance of $\mathrm{Fe}-\mathrm{Cr}-\mathrm{Al}$ based alloys // Functional materials. 2020, v. 27, N 1, p. 7986.

29. B.A. Pint, K.A. Unocic. Steam Oxidation Evaluation of $\mathrm{Fe}-\mathrm{Cr}$ Alloys for Accident Tolerant Nuclear Fuel Cladding // Oxidation of Metals. 2017, v. 87 , p. 515-526.

Статья поступила в редакцию 25.03.2021 2.

\title{
СТРУКТУРА И СВОЙСТВА FеСr-, CrAl- И FеСrAl-ПОКРЫТИЙ, ОСАЖДЕННЫХ ВАКУУМНОЙ ДУГОЙ
}

\author{
Р.Л. Василенко, В.Н. Воеводин, В.А. Белоус, М.А. Бортницкая, И.В. Колодий, И.О. Клименко, \\ В.Д. Овчаренко, В.И. Коваленко, В.Г. Маринин, А.В. Ильченко, М.А. Тихоновский, А.С. Куприн
}

Вакуумно-дуговым способом нанесены покрытия различного состава из катодов $\mathrm{Fe}, \mathrm{Cr}, \mathrm{Al}$ и $\mathrm{CrAl}$ на фрагменты твэльных оболочек из сплава $\mathrm{Zr}-1 \% \mathrm{Nb}$. Исследованы структурные особенности, механические и коррозионные свойства осажденных покрытий. Установлено влияние состава и структуры разработанных покрытий на их физико-механические свойства (микротвердость, устойчивость к коррозии и абразивному, и кавитационному воздействию). Показано, что оптимальным сочетанием механических свойств и высокой стойкостью к окислению из серии исследованных покрытий: $\mathrm{FeCr}, \mathrm{FeCrAl}$ и $\mathrm{CrAl}$, имеют покрытия системы $\mathrm{FeCrAl}$ с концентрацией $\mathrm{Cr} \sim 22$ ат.\% и $\mathrm{Al} \sim 14,3$ ат.\%. Установлено, что покрытия типа фехраль $\mathrm{FeCrAl}$ и $\mathrm{CrAl}$ толщиной 12 мкм существенно повышают устойчивость к окислению и предотвращают разрушение оболочек твэлов в условиях окисления на воздухе при температуре $1150{ }^{\circ} \mathrm{C}$ в течение 1 ч.

\section{СТРУКТУРА ТА ВЛАСТИВОСТІ FеCr-, CrAl- I FеCrAl-ПОКРИТТІВ, ОСАДЖЕНИХ ВАКУУМНОЮ ДУГОЮ}

\author{
Р.Л. Василенко, В.М. Воєводін, В.А. Білоус, М.О. Бортницька, І.В. Колодій, І.О. Кліменко, \\ В.Д. Овчаренко, В.І. Коваленко, В.Г. Маринін, О.В. Ільченко, М.А. Тихоновський, О.С. Купрін
}

Вакуумно-дуговим методом нанесені захисні покриття різного складу з катодів $\mathrm{Fe}, \mathrm{Cr}, \mathrm{Al}$ та $\mathrm{CrAl}$ на фрагменти твельних оболонок зі сплаву Zr-1\% Nb. Досліджені структурні особливості, механічні та корозійні властивості осаджених покриттів. Встановлено вплив складу та структури розроблених покриттів на їх фізико-механічні властивості (мікротвердість, стійкість до корозії та кавітаційного і абразивного зносу). Показано, що оптимальним поєднанням механічних властивостей і високою стійкістю до окислення 3 серії досліджених покриттів: $\mathrm{FeCr}, \mathrm{FeCrAl}$ та $\mathrm{CrAl}$, мають покриття системи $\mathrm{FeCrAl} 3$ концентрацією $\mathrm{Cr} \sim 22$ ат.\% та $\mathrm{Al} \sim 14,3$ ат.\%. Встановлено, що захисні покриття типу фехраль $\mathrm{FeCrAl}$ та $\mathrm{CrAl}$ товщиною 12 мкм суттєво підвищують стійкість до окислення та запобігають руйнуванню оболонок твелів в умовах окислення на повітрі при температурі $1150{ }^{\circ} \mathrm{C}$ впродовж 1 год. 